\title{
Lead and zinc removal with storage period in porous asphalt pavement
}

\author{
Yao Zhao and Chen Zhao* \\ College of Civil Engineering, Nanjing Forestry University, Nanjing 210037, China
}

\section{ABSTRACT}

Porous asphalt pavements have been used as an effective technique to overcome road runoff challenges, and to improve efficiency of rainwater utilisation in urban areas. Using porous asphalt pavements with reservoir storage and harvesting facilities is an important consideration for the future. This study monitored changes in water quality indicators, such as $\mathrm{pH}$, conductivity, and concentrations of lead and zinc, for water stored in porous asphalt pavement models with basalt-, limestone- and 'basalt+limestone'-filled reservoir structures. The research discusses findings over a 696-h storage period following artificial rainfall. Total lead and zinc concentrations were remarkably reduced throughout the initial flush, showing, on average, reductions of $90 \%$ and $80.5 \%$, respectively. This pattern was consistent throughout the storage period, producing average reductions in lead and zinc of $99.98 \%$ and $79 \%$, respectively, over $696 \mathrm{~h}$. Conductivity and pH levels increased in all pavement models after the 696 -h storage. The results obtained confirmed the potential of using porous asphalt pavements with reservoir structures to remove heavy metals from road runoff. This can be applied to future research on the removal mechanisms of porous asphalt pavements in relation to heavy metals in road runoff.

Keywords: heavy metals, road runoff, porous asphalt pavement, retention

\section{INTRODUCTION}

Urbanisation has resulted in a rapid growth of impermeable surfaces over the past decades, such as roofs, squares, car parks and roads. Due to the decreasing space available for water penetration, this change has significantly influenced the hydrologic characteristics of stormwater runoff, by increasing runoff peak flow rates and peak velocities, and decreasing lag time and water quality (Field et al., 1982). Over time, several principal problems have emerged, including city flooding, lowering groundwater levels, and surface water pollution.

Large amounts of pollutants, including sediment (e.g., total suspended sediments (TSS)), nutrients (e.g., total Kjeldahl nitrogen (TKN)), oil and toxic chemicals from automobiles (e.g., total petroleum hydrocarbons (TPHs)), and heavy metals (e.g., lead, copper and zinc), are carried by stormwater runoff from impermeable surfaces during rainfall events (Singhal et al., 2008; Lee et al., 2011; Shinya et al., 2000; Helmreich et al., 2010), and are thus discharged into nearby water ecosystems without any treatment (Ukabiala Chinwe et al., 2010; Lee et al., 2011). Among many other pollutants, heavy metals are highly hazardous due to their toxicity, non-biodegradation, and mass accumulation (Zuo et al., 2012; Zhang et al., 2012; Singh et al., 2011; Nie et al., 2008; Fuerhacker et al., 2011). Heavy metal accumulation in receiving waters can have a significant impact on aquatic organisms by absorption and bioaccumulation, potentially contaminating the local marine ecosystem (Vardanyan et al., 2006). Once heavy metals enter the food chain, they may accumulate to dangerous levels and be harmful to human life and other organisms (Zhang et al., 2012; Ip et al., 2005). As a result, stormwater runoff from impermeable

\footnotetext{
To whom all correspondence should be addressed.

용 +8625 85428919; fax: +8625 85428919;

e-mail: czh@njfu.edu.cn

Received 1 March 2013; accepted in revised form 17 December 2013.
}

pavements is often regarded as an important source of pollution, particularly as such pavement areas in urban spaces are said to occupy twice the land area occupied by buildings (Ferguson, 2005). With respect to the receiving water environment (Murakami et al., 2009), treatment to remove heavy metals from road runoff is of high importance, and applicable to many countries around the world, both for stormwater mitigation, and water harvesting and reuse potential.

Porous asphalt pavements have been successfully installed in many countries as an effective method to overcome road runoff challenges, with their innovative design boasting benefits above those of conventional asphalt pavements (Zhao et al., 2012). Designed with built-in networks of void spaces, water and air can pass through the surface, base course and reservoir structures, finally entering the receiving environment (Legret et al., 1999; Roseen et al., 2012; Ferguson, 2005). As a result of this design, porous asphalt pavements are not only of benefit to the physical hydrology, reducing runoff peak and peak velocities during rainfall events, but also a beneficial way to improve the water quality of runoff. Some field studies have shown that porous asphalt pavements can provide benefits such as the removal of heavy metals from road runoff, in the long term. Early in 1987, Hogland et al. reported water quality improvement performance of several porous asphalt sites receiving snowmelt over a 1-year period. They found that a reduction of zinc by $17 \%$ was achieved by the porous asphalt pavement. Legret et al. (1996) reported heavy metal ion adsorption for a porous asphalt pavement with reservoir structure in Rezé, France, during a 4-year survey that showed a reduction of lead and zinc by $79 \%$ and $67 \%$, respectively. Similarly, Baladès et al. (1995) reported that, over a period of 3 years, a reduction of lead by $93 \%$ was obtained from 3 sites in Bordeaux, France. Briggs (2006) reported a reduction of zinc by $96 \%$ over 1 year from a porous asphalt site in Durham, New Hampshire; in addition, Roseen et al. (2012) reported zinc removal of 95\%, also over 1 year. 


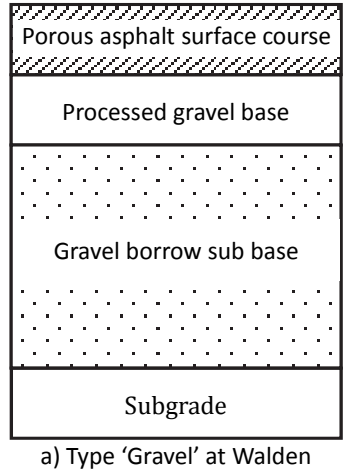

a) Type 'Gravel' at Walden Pond

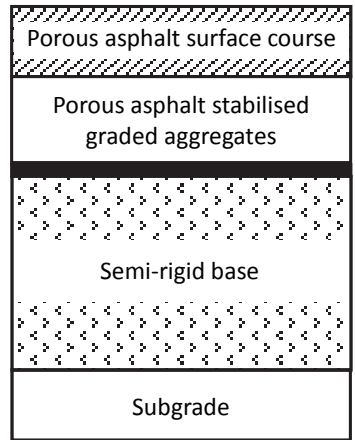

b) Type 'III' in Technical Specification
In addition to these benefits, the use of porous asphalt pavements with reservoir structures for harvesting and storage is an important consideration, particularly with 'fit for purpose' reuse in mind. There are few studies examining the effect of porous asphalt pavements with different reservoir structures on heavy metal removal over periods longer than what might be deemed 'temporary' storage, though several studies have focused on pollutant removal from road runoff with rainfall events, rather than storage time. In 2007 and 2011, Myers et al. investigated the influence of residence time on stored water quality, for a period up to $144 \mathrm{~h}$. Results showed that both total zinc and total lead were reduced by $99 \%$ after $144 \mathrm{~h}$ storage in dolomite- and calcite-filled reservoir structures.

Building on the above research, this paper reports the influence of porous asphalt pavements with 3 different reservoir structures on heavy metal (lead and zinc) removal from road runoff over a long storage period, incorporating simulated rainfall events. Several water quality parameters were observed in the effluent samples from 3 porous asphalt pavements with basalt, limestone or 'basalt+limestone' filled reservoir structures, over a $696-\mathrm{h}$ period. The potential of using porous asphalt pavements is discussed with respect to road runoff for water irrigation and reuse in China. Results of this study can be used to assess the suitability of adopting porous asphalt pavements as a mechanism for water harvesting, storage and reuse management in the long term, particularly noting applicable material for reservoir structures.

\section{EXPERIMENTAL}

Porous asphalt pavement models were installed in 3 test-rigs, where synthetic stormwater was applied through an artificial rainfall simulator. Effluent samples were then collected from the sampling pipe to investigate the effects of porous asphalt pavement with basalt, limestone and 'basalt+limestone' filled reservoir structures on total lead and zinc removal from stored water, within the storage time.

\section{Pavement models}

Three laboratory-scale porous asphalt pavement models were installed. The test-rig was made of stainless steel with a diameter of $15 \mathrm{~cm}$ (with a cross-sectional area of $0.018 \mathrm{~m}^{2}$ ) and a height of $70 \mathrm{~cm}$. As shown in Fig. 1, the structure of the porous asphalt pavement model consists of:

- Sub-base: a woven geotextile

- Reservoir structure: $35 \mathrm{~cm}$ layer of $13.2 \mathrm{~mm}$ crushed stones

- Processed course: $12 \mathrm{~cm}$ layer of porous asphalt stabilised graded aggregates

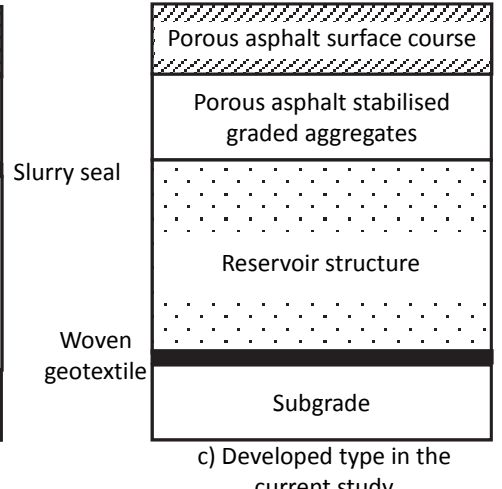

Figure 1

Comparison of different porous asphalt pavement structures
- Surface course: $9 \mathrm{~cm}$ layer of porous asphalt

The porous asphalt pavement structure followed the type 'Gravel' (Ferguson, 2005), which had been successfully used at Walden Pond State Reservation in Concord, Massachusetts, USA, comprising a relatively thin layer of processed material above the reservoir structure, and immediately under the surface layer. In this study, a woven geotextile was added under the reservoir structure for water quality improvement; this is also a mechanism to separate the structure from the underlying soil while allowing water to infiltrate the subgrade. Moreover, this pavement model design is in accordance with the technical specifications for permeable asphalt pavements in China (CMHURD, 2012).

The surface layer was designed with an open-graded porous asphalt mixture: $20 \%$ designed air void and a $5.5 \%$ asphaltaggregate ratio; the processed layer was built with an $18 \%$ designed air void and a 5.0\% asphalt-aggregate ratio; and the reservoir structures were filled with different materials (basalt and limestone were chosen as they are commonly used as pavement materials in the field in Jiangsu Province, China):

- 'Basalt+limestone'-filled: 50\% basalt crushed gravel (13.2 $\mathrm{mm}$ ) mixed with 50\% limestone crushed gravel $(13.2 \mathrm{~mm})$

- Basalt-filled: $100 \%$ basalt crushed gravel of $13.2 \mathrm{~mm}$

- Limestone-filled: $100 \%$ limestone crushed gravel of $13.2 \mathrm{~mm}$

- Pavement models were placed in a well-ventilated room that provided consistent environmental conditions throughout the experimental period, removing the potential for additional light and subsequent increased temperature to increase the internal temperature and thus affect the physical and chemical processes that were being monitored.

\section{Porous asphalt mixture}

High viscosity modified asphalt supplied by Jiangsu Baoli Asphalt Co. Ltd, a professional manufacturer of asphalt materials in China, was used in this study. Table 1 shows the requirements for high viscosity asphalt, as specified in the current Chinese standards (CMC, 2006; CMC, 2011; CMHURD, 2012), and the test results for the asphalt used in this study. The gradations for surface layers and processed layers adopted were developed based on the theory of aggregate packing. The detailed procedure used was an extension of methods presented in the technical specification for permeable asphalt pavement (CMHURD, 2012). From this procedure, the optimal asphalt content was determined through binder drainage and Cantabro tests. Figure 2 shows the aggregate gradations used in this investigation. In order to inhibit asphalt drain-down, and 


\begin{tabular}{|c|c|c|c|c|c|}
\hline \multicolumn{6}{|c|}{$\begin{array}{c}\text { TABLE } 1 \\
\text { Comparison between requirements for high-viscosity asphalt and test results }\end{array}$} \\
\hline \multicolumn{2}{|r|}{ (1) p } & Unit & Requirement & Test results & Test method \\
\hline \multicolumn{2}{|c|}{ Penetration $\left(25^{\circ} \mathrm{C}, 100 \mathrm{~g}, 5 \mathrm{~s}\right)$} & $1 / 10 \mathrm{~mm}$ & $\geq 40$ & 56 & T 0604-2011 \\
\hline \multicolumn{2}{|c|}{ Softening point $(\mathrm{R} \& \mathrm{~B})$} & ${ }^{\circ} \mathrm{C}$ & $\geq 80$ & 90 & T 0606-2011 \\
\hline \multirow[t]{2}{*}{ Ductility } & $\left(15^{\circ} \mathrm{C}\right)$ & $\mathrm{cm}$ & $\geq 50$ & 60 & \multirow[t]{2}{*}{ T 0605-2011 } \\
\hline & $\left(5^{\circ} \mathrm{C}\right)$ & $\mathrm{cm}$ & $\geq 20$ & 40 & \\
\hline \multirow{2}{*}{$\begin{array}{l}\text { RIFOT } \\
\text { Residue }\end{array}$} & Mass loss & $\%$ & $\leq 0.6$ & 0.01 & \multirow[t]{2}{*}{ T 0610-2011 } \\
\hline & Retained penetration & $\%$ & $\geq 65$ & 85 & \\
\hline \multicolumn{2}{|c|}{ Toughness $\left(25^{\circ} \mathrm{C}\right)$} & $\mathrm{Nm}$ & $\geq 20$ & 40 & T 0624-2011 \\
\hline \multicolumn{2}{|c|}{ Tenacity $\left(25^{\circ} \mathrm{C}\right)$} & $\mathrm{Nm}$ & $\geq 15$ & 22 & T 0624-2011 \\
\hline \multicolumn{2}{|c|}{ Viscosity $\left(60^{\circ} \mathrm{C}\right)$} & Pas & $\geq 20000$ & 126300 & T 0620-2000 \\
\hline \multicolumn{2}{|l|}{ Flash point } & ${ }^{\circ} \mathrm{C}$ & $\geq 260$ & 300 & T 0611-2011 \\
\hline Separation & Softening point difference & ${ }^{\circ} \mathrm{C}$ & $\leq 2.5$ & 0.2 & T 0661-2011 \\
\hline
\end{tabular}

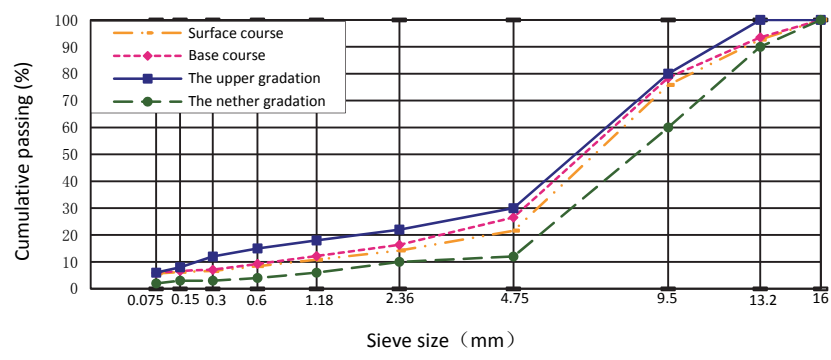

Figure 2

Gradations of surface course and base course for porous asphalt pavement models

prolong bonding, each gradation incorporated a $0.3 \%$ catkin form cellulose fibres (Kuennen, 2003; CMHURD, 2012).

A vibrating method was used for preparing porous asphalt mixtures, due to its greater efficiency over the Marshall Method, when the asphalt mixture is designed with more than $60 \%$ coarse aggregates (Xie et al., 2009).

\section{Synthetic stormwater}

To ensure accuracy of the investigation, a synthetic stormwater was prepared, based on the methods reported by Davis et al. (2003) and Myers et al. (2007; 2011), using ultrapure water to provide consistent water quality. The target pollutants and concentrations in synthetic stormwater were determined based on a report of road runoff quality in Nanjing, China (Yu et al., 2008); however, for this study the concentration of lead was multiplied by 100 providing a 'worst case scenario' to quantify severe impacts on plants, animals and humans. Table 2 presents the pollutant levels of synthetic stormwater used in this study.

Natural organic matter present in stormwater was simulated by adding aqueous extract of dried leaf material, prepared as reported by Myers et al. (2007). Although synthetic stormwater contained organics, this paper presents and discusses only the results for lead and zinc.

\section{EXPERIMENTS AND PROCEDURES}

Following preparation of pavement models, an artificial rainfall simulator consisting of a sprinkler with injection needles, a control system, and a storage tank, was installed (as shown in Fig. 3). The necessary spray volume for an equivalent simulated year was calculated following the method reported by Brown et al. (2009). The following formula was used to calculate the necessary applied volume:

$$
V=\mathrm{d} A(I / P+1)
$$

where:

$V$ is the equivalent volume of annual precipitation $\left(\mathrm{m}^{3}\right)$

$d$ is the average annual depth of precipitation in Nanjing (m)

$A$ is the permeable pavement area $\left(\mathrm{m}^{2}\right)$

$I / P$ is the ratio of impervious area to pervious area

(dimensionless).

For the pavement models, the total surface area was 0.018 $\mathrm{m}^{2}$, the average annual precipitation in Nanjing was $1.1252 \mathrm{~m}$ (2001-2010), and an $I / P$ of 4 was assumed. Therefore, $10.125 \ell$ water was required to simulate 1 year of stormwater runoff for each laboratory pavement model.

Pavement models all had an applied flow rate of $0.0026 \mathrm{l} / \mathrm{s}$ (equal to $52.5 \mathrm{~mm} / \mathrm{h}$ ), pumped from the storage tank continuously, and fed through a sprinkler. The rainfall intensity was measured and recorded by a rain gauge; 1-year's rainfall (totalling $30.375 \mathrm{l}$ ) was simulated for all pavement models. Following the application of artificial rainfall, the sampling pipes (as shown in Fig. 3) were immediately closed, thus allowing storage of the synthetic stormwater runoff.

For effluent sampling, the plastic bottles were soaked in nitric acid solution (volume ratio, 1:500) over $24 \mathrm{~h}$ and washed by ultra-pure water before use. The concentrations of lead and zinc, conductivity and $\mathrm{pH}$ of the synthetic stormwater were measured before artificial rainfall. To analyse the initial

\begin{tabular}{|l|l|l|l|}
\hline \multicolumn{5}{|c|}{ TABLE 2 } \\
\hline Item & $\begin{array}{l}\text { Concentration } \\
\text { range in literature }\end{array}$ & Chemical & $\begin{array}{l}\text { Target } \\
\text { concentration }\end{array}$ \\
\hline Organics & $189 \mathrm{mg} / \ell$ & Aqueous extract of dried leaves & - \\
\hline Zinc & $0.18-1.92 \mathrm{mg} / \ell$ & $\mathrm{Zn}\left(\mathrm{NO}_{3}\right)_{2}(1000 \mathrm{mg} / \ell)$ & $0.51 \mathrm{mg} / \ell$ \\
\hline Lead & $20-170 \mu \mathrm{g} / \ell$ & $\mathrm{Pb}\left(\mathrm{NO}_{3}\right)_{2}(1000 \mathrm{mg} / \ell)$ & $21.24 \mathrm{mg} / \ell$ \\
\hline
\end{tabular}




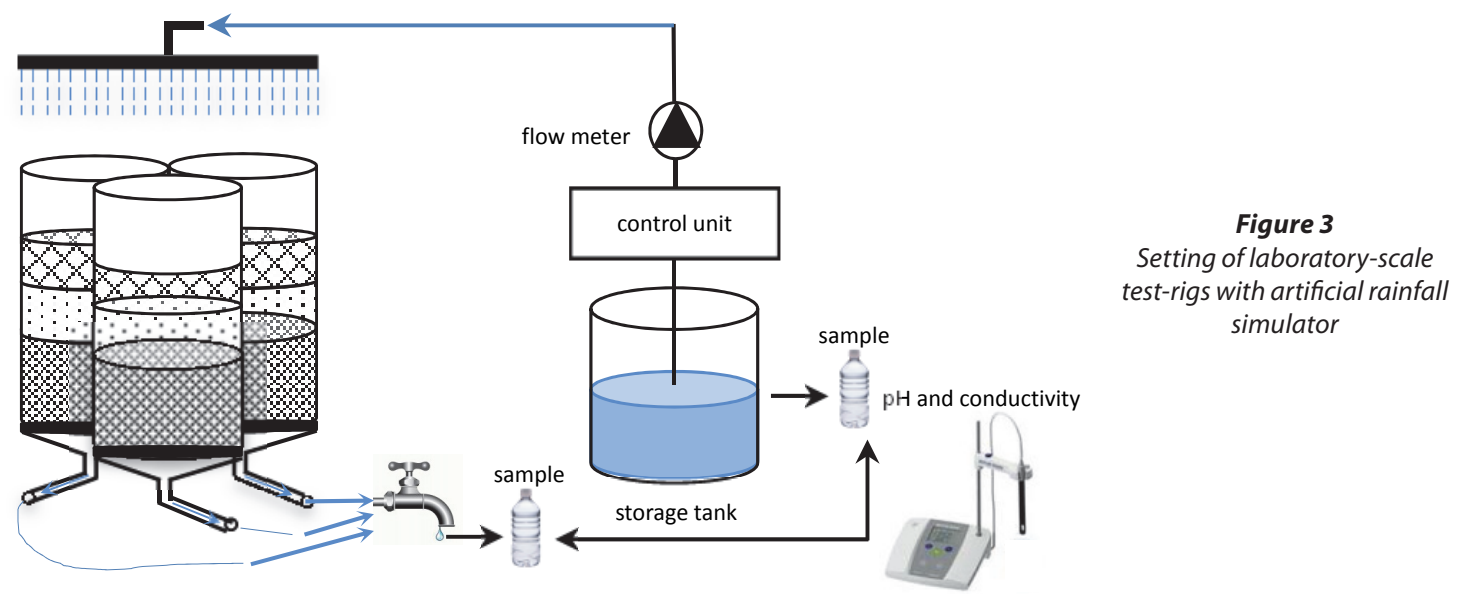

effects on lead and zinc removal, a $2 \ell$ effluent sample was taken immediately from the sampling pipe when the initial flush occurred. Unlike first flush, which occurs on road surfaces at the beginning of rainfall, initial flush in this study refers to the initial outlet water from porous asphalt pavement models, after the artificial rainfall experiment.

Subsequent effluent samples were then collected at predetermined sampling times (the sampling time was selected to extend up to $696 \mathrm{~h}$ due to the observed levels of change in most parameters between 552 and $696 \mathrm{~h}$ ).

\section{Sample analysis}

At each sampling event, the values of $\mathrm{pH}$ and conductivity were measured directly by $\mathrm{pH}$ meter (PHSJ-5, China) and conductivity meter (EC214, Italy). Water samples were digested using a microwave oven (WX-3000, China) and then analysed for total lead and zinc, using inductively coupled plasma atomic emission spectrometry (4300DV, America). Both sampling and analysis strictly followed standard methods (EPAC, 1987).

\section{RESULTS AND DISCUSSION}

\section{pH and conductivity}

Changes in $\mathrm{pH}$ and conductivity of effluents from the porous asphalt pavement models are presented in Figs. 4 and 5, respectively. After $1 \mathrm{~h}$, the $\mathrm{pH}$ levels of effluents from the 'basalt+limestone'-, basalt-, and limestone-filled reservoir structures dropped to 5.9, 6.1 and 6.0 in the first $48 \mathrm{~h}$, after initially rising by $0.2,0.3$ and 0.3 , respectively. By contrast, the $\mathrm{pH}$ levels of effluents from both basalt- and limestone-filled reservoirs showed little change in the final $417 \mathrm{~h}$, whereas the curve of $\mathrm{pH}$ from the 'basalt+limestone' reservoir was concave in these final hours. The overall $\mathrm{pH}$ levels from the 'basalt+limestone' reservoir were lower than the basalt reservoir and limestone reservoir, for all sampling events, with exceptions between 72 and $192 \mathrm{~h}$.

Conductivity levels in effluents from the 'basalt+limestone', basalt, and limestone reservoirs varied in the first $48 \mathrm{~h}$; several obvious fluctuations in the 'basalt+limestone' reservoir were observed, meanwhile, gradual increases occurred in the basalt and limestone reservoirs. However, following the first $48 \mathrm{~h}$, conductivity levels in effluents from all three pavement models showed a similar trend of a gradual, increase. The conductivity increase was higher in porous asphalt pavement with basalt reservoir, than in porous asphalt pavement with 'basalt+limestone'

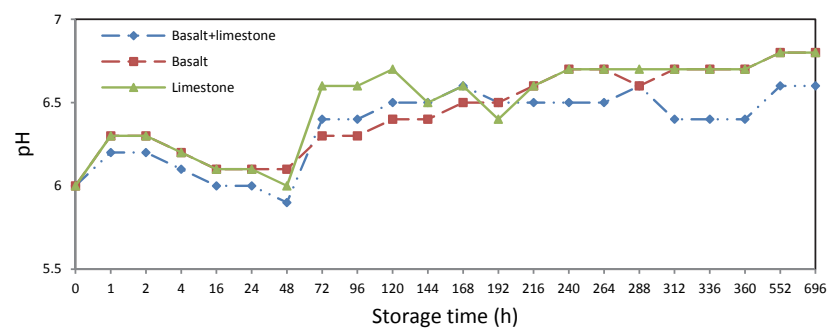

Figure 4

Changes in $\mathrm{pH}$ over the storage period of $696 \mathrm{~h}$

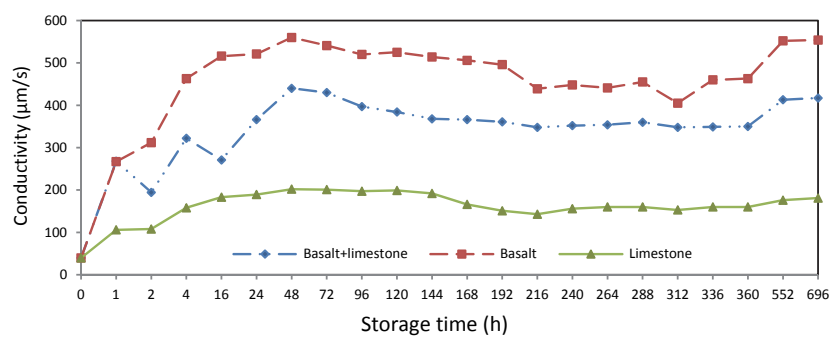

Figure 5

Changes in conductivity over the storage period of $696 \mathrm{~h}$

and limestone reservoirs. By contrast, the conductivity of effluents in the porous asphalt pavement with limestone reservoir was steady, showing no siginficant increase or decrease after $48 \mathrm{~h}$.

Changes in the $\mathrm{pH}$ and conductivity of effluents from all models with reservoir structures may be attributable to the dissolution process of the aggregate constituents. Similar changes in the $\mathrm{pH}$ of water in basalt reservoirs and limestone reservoirs has been found in previous studies. In acidic solutions, the hydrogen ions are exchanged with the monovalent, bivalent and trivalent ions on the surface of the basalt aggregate, resulting in a soluble activated complex that could increase the solution $\mathrm{pH}$, and finally make it neutral. The concentrations of dissolved silicon, calcium, magnesium and potassium from basalt in the solution increased with reaction time until equilibrium was reached (Dang et al., 1995). In the case of limestone, which is primarily composed of lime carbonate, the process appeared much slower than the basalt, and 'basalt+limestone' reservoirs. Due to dissolution of minor fractions, the $\mathrm{pH}$ and chemistry of the solution were also affected, resulting in an increasing $\mathrm{pH}$ finally reading 7.0 (Xu et al., 2008). Unfortunately, conductivity was not measured in the studies referred to above. 


\begin{tabular}{|l|c|c|c|c|c|c|}
\hline \multicolumn{7}{|c|}{ TABLE 3} \\
Water quality analysis of initial flush \\
\hline Materials for reservoir structure & 'Basalt+limestone' & \multicolumn{2}{|c|}{ Basalt } & \multicolumn{2}{c|}{ Limestone } \\
\hline Heavy metals & Lead & Zinc & Lead & Zinc & Lead & Zinc \\
\hline Concentrations of synthetic stormwater $(\mathrm{mg} / \ell)$ & 21.24 & 0.51 & 21.24 & 0.51 & 21.24 & 0.51 \\
\hline Concentrations of initial flush $(\mathrm{mg} / \ell)$ & 2.357 & 0.191 & 2.609 & 0.141 & 1.704 & ND \\
\hline Deduction of initial flush* $(\%)$ & 88.90 & 62.55 & 87.72 & 72.35 & 91.98 & 99.90 \\
\hline Limits for irrigation water $(\mathrm{mg} / \ell)$ & 0.2 & 2.0 & 0.2 & 2.0 & 0.2 & 2.0 \\
\hline Limits for reclaimed water $(\mathrm{mg} / \ell)$ & & & & & & \\
(1) For groundwater recharge & 0.01 & - & 0.01 & - & 0.01 & - \\
(2) For planting, rangeland, farm and aquaculture & 0.1 & - & 0.1 & - & 0.1 & - \\
\hline
\end{tabular}

$\underset{*}{N}$, below detection limit (detection limits for lead and zinc were 3.8 and $0.5 \mu \mathrm{g} / \ell$, respectively)

${ }^{*}$ Calculated as the detection limit when the concentration is below detection limit

In this study, $\mathrm{pH}$ levels did not exceed the limited range of 5.5-8.8 for irrigation water quality (CGAQIQ and CNSMC, 2005); however, during the first $192 \mathrm{~h}$ levels exceeded the range of 6.5-9.0 recommended for reclaimed water (CWM, 2006). Based on the above results, it is recommended that the water drained immediately from porous asphalt pavement with basalt- or limestone-filled reservoir structures should not be used as reclaimed water.

\section{Initial flush characteristics}

Table 3 shows the concentrations and removal efficiencies for total lead and zinc in the initial flush from all test models. The concentrations of total lead and zinc in the initial flush effluent were much lower than in synthetic stormwater. The removal efficiencies for total lead in effluents from 'basalt+limestone', basalt, and limestone reservoirs were $88.90 \%, 87.72 \%$ and 91.98\%; and for total zinc were $62.55 \%, 72.35 \%$ and $99.90 \%$, respectively. Different removal efficiencies for lead and zinc measured in the samples implied that heavy metal ion removal efficiencies might differ with various reservoir aggregates; however, the results from this study proved inconclusive.

As mentioned above, heavy metal contaminants in water produce a huge risk for irrigation due to their toxicity, nonbiodegradation, and potential for mass accumulation (Zuo et al., 2012; Zhang et al., 2012; Singh et al., 2011; Nie et al., 2008; Fuerhacker et al., 2011). Table 3 also shows the limits for irrigation water and reclaimed water in urban areas in China. It is recommended that the water drained immediately from porous asphalt pavements with basalt, limestone, or 'basalt+limestone' filled reservoirs should not be used as irrigation water or reclaimed water in urban areas (CGAQIQ and CNSMC, 2005; CWM, 2006), regardless of the high performances for removal efficiency.

\section{Change in lead concentration}

Changes in lead concentration over the storage period of 696 $\mathrm{h}$ are depicted in Fig. 6 and Table 4. The concentrations of total lead measured in effluents from porous asphalt pavement models with 'basalt+limestone', basalt-, and limestone-filled reservoir structures were significantly lower than in synthetic stormwater after $1 \mathrm{~h}$, with mean values of $0.639,0.311$ and 0.168 $\mathrm{mg} / \ell$, respectively, implying, a $96.99 \%, 98.54 \%$ and $99.21 \%$ lead removal rate during the first hour. In the following $143 \mathrm{~h}$, the removal efficiencies were over $98.55 \%$, although some fluctuations were observed. Overall, the removal of lead in porous asphalt pavement models with 'basalt+limestone', basalt, and

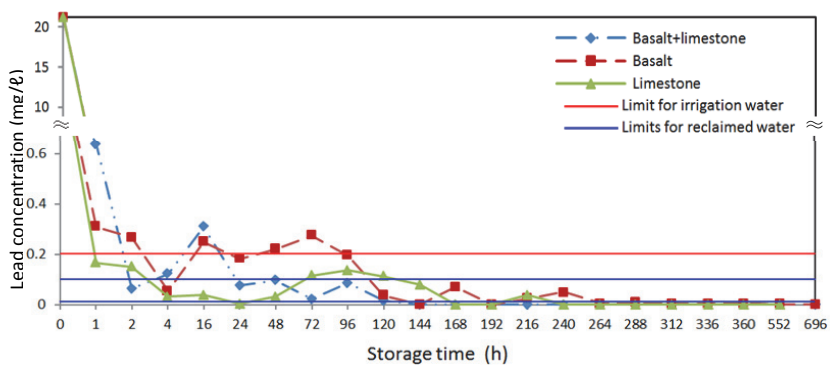

Figure 6

Changes in lead concentration over the storage period of $696 \mathrm{~h}$

limestone reservoir structures was between 96.99 and 99.98\%, 98.54 and $100 \%$ and 99.21 and $100 \%$, respectively. In summary, the results for lead indicate that porous asphalt pavements with 'basalt+limestone', basalt-, and limestone-filled reservoirs can effectively remove lead from road runoff in both short and longer storage periods. In this case it is important to note that the removal efficiencies increased with storage time.

The fluctuations in lead concentration are possibly influenced by the dissolution process of the aggregate constituents; however, there is no direct evidence to support this. The changes in the $\mathrm{pH}$ and conductivity only imply that excessive ions and products appeared in the stored water. Constituents of basalt are more complex than limestone, releasing more elements into the solution. Therefore, the fluctuations of lead concentrations in effluents from the 'basalt+limestone' and basalt reservoirs were more obvious in the first $144 \mathrm{~h}$. Over time, dissolved silicon and aluminium in the solution, from basalt, could form a colloidal complex on the surface with the increasing reaction time (Dang et al., 1995). As a result, there was no significant change in lead concentration after $144 \mathrm{~h}$. For limestone reservoirs, dissolved lime carbonate from limestone increased calcium in the solution, resulting in an increased surface roughness (Xu et al., 2008). Therefore, the fluctuations in lead concentration in effluent from the limestone reservoir were lower than for the effluent from the basalt reservoir during the initial $144 \mathrm{~h}$, later stabilising.

The removal of lead is likely due to adsorption by the material (asphalt on pore-walls in upper layers or the aggregate material in reservoir structure), and precipitation with the products of basalt and limestone. The essential mineral of limestone is calcite, which has been explored as a sorbent for heavy metals in previous studies (Al-Degs et al., 2006; Myers et al., 2007; Xing, 2007), and the mechanism of $\mathrm{Pb}(\mathrm{II})$ removal was mainly 'precipitation' by metal carbonate complexes. 


\begin{tabular}{|c|c|c|c|c|c|c|c|c|c|c|c|c|}
\hline \multicolumn{13}{|c|}{$\begin{array}{c}\text { TABLE } 4 \\
\text { Effluent performance summary for laboratory experiment }\end{array}$} \\
\hline \multirow{3}{*}{$\begin{array}{l}\text { Reservoirs } \\
\text { Sampling } \\
\text { events (h) }\end{array}$} & \multicolumn{4}{|c|}{ 'Basalt+limestone' } & \multicolumn{4}{|l|}{ Basalt } & \multicolumn{4}{|c|}{ Limestone } \\
\hline & \multicolumn{2}{|c|}{$\begin{array}{l}\text { Concentration } \\
(\mathrm{mg} / \mathrm{l})\end{array}$} & \multicolumn{2}{|c|}{$\begin{array}{l}\text { Reduction* } \\
(\%)\end{array}$} & \multicolumn{2}{|c|}{$\begin{array}{l}\text { Concentration } \\
(\mathrm{mg} / \mathrm{\ell})\end{array}$} & \multicolumn{2}{|c|}{$\begin{array}{l}\text { Reduction } \\
(\%)\end{array}$} & \multicolumn{2}{|c|}{$\begin{array}{l}\text { Concentration } \\
(\mathrm{mg} / \ell)\end{array}$} & \multicolumn{2}{|c|}{$\begin{array}{l}\text { Reduction* } \\
(\%)\end{array}$} \\
\hline & lead & zinc & lead & zinc & lead & zinc & lead & zinc & lead & zinc & lead & zinc \\
\hline 1 & 0.639 & 0.913 & 96.99 & -79.02 & 0.311 & 5.186 & 98.54 & -916.86 & 0.168 & 0.182 & 99.21 & 64.31 \\
\hline 2 & 0.065 & 0.644 & 99.69 & -26.27 & 0.268 & 12.27 & 98.74 & -2305.88 & 0.152 & 1.035 & 99.28 & -102.94 \\
\hline 4 & 0.123 & 1.42 & 99.42 & -178.43 & 0.054 & 2.693 & 99.75 & -428.04 & 0.034 & 0.372 & 99.84 & 27.06 \\
\hline 16 & 0.308 & 6.752 & 98.55 & -1223.92 & 0.25 & 9.461 & 98.82 & -1755.10 & 0.039 & 4.576 & 99.82 & -797.25 \\
\hline 24 & 0.076 & 2.423 & 99.64 & -375.10 & 0.183 & 6.073 & 99.14 & -1090.78 & 0.005 & 1.693 & 99.98 & -231.96 \\
\hline 48 & 0.097 & 5.113 & 99.54 & -902.55 & 0.221 & 6.214 & 98.96 & -1118.43 & 0.032 & 8.087 & 99.85 & -1485.69 \\
\hline 72 & 0.023 & 3.428 & 99.89 & -572.16 & 0.276 & 4.279 & 98.70 & -739.02 & 0.147 & 6.64 & 99.31 & -1201.96 \\
\hline 96 & 0.087 & 2.824 & 99.59 & -453.73 & 0.195 & 4.346 & 99.08 & -752.16 & 0.137 & 6.728 & 99.35 & -1219.22 \\
\hline 120 & 0.017 & 2.836 & 99.92 & -456.08 & 0.037 & 1.371 & 99.83 & -168.82 & 0.113 & 5.51 & 99.47 & -980.39 \\
\hline 144 & ND & 1.703 & 99.98 & -233.92 & 0 & 0.508 & 100.00 & 0.39 & 0.082 & 5.288 & 99.61 & -936.86 \\
\hline 168 & ND & 0.282 & 99.98 & 44.71 & 0.072 & 0.471 & 99.66 & 7.65 & 0 & 1.661 & 100.00 & -225.69 \\
\hline 192 & ND & 0.529 & 99.98 & -3.73 & 0.001 & 0.379 & 100.00 & 25.69 & ND & ND & 99.98 & 99.90 \\
\hline 216 & ND & 0.304 & 99.98 & 40.39 & 0.025 & 0.744 & 99.88 & -45.88 & ND & 0.962 & 99.98 & -88.63 \\
\hline 240 & ND & 0.623 & 99.98 & -22.16 & 0.051 & 0.614 & 99.76 & -20.39 & ND & 0.66 & 99.98 & -29.41 \\
\hline 264 & ND & 0.362 & 99.98 & 29.02 & 0.006 & 0.515 & 99.97 & -0.98 & ND & 0.498 & 99.98 & 2.35 \\
\hline 288 & ND & 0.245 & 99.98 & 51.96 & 0.01 & 0.731 & 99.95 & -43.33 & ND & 1.347 & 99.98 & -164.12 \\
\hline 312 & ND & ND & 99.98 & 99.90 & 0.005 & 0.631 & 99.98 & -23.73 & ND & 0.025 & 99.98 & 95.10 \\
\hline 336 & ND & 0.061 & 99.98 & 88.04 & 0.004 & 0.262 & 99.98 & 48.63 & ND & 0.016 & 99.98 & 96.86 \\
\hline 360 & ND & 0.038 & 99.98 & 92.55 & 0.007 & 0.288 & 99.97 & 43.53 & ND & ND & 99.98 & 99.90 \\
\hline 552 & ND & ND & 99.98 & 99.90 & 0.002 & 0.277 & 99.99 & 45.69 & ND & ND & 99.98 & 99.90 \\
\hline 696 & ND & 0.031 & 99.98 & 93.92 & ND & 0.213 & 99.98 & 58.24 & ND & ND & 99.98 & 99.90 \\
\hline
\end{tabular}

$N D$, below detection limit (detection limits for lead and zinc were 3.8 and $0.5 \mu \mathrm{g} / \mathrm{\ell}$, respectively)

${ }^{*}$ Calculated as the detection limit when the concentration below detection limit

Unfortunately, no study has explored the mechanism responsible for removal of heavy metals by basalt.

The levels of lead in effluents from the 'basalt+limestone'-, basalt-, and limestone-filled reservoirs did not exceed the $0.2 \mathrm{mg} / \ell$ limit for irrigation water after 24,96 or $1 \mathrm{~h}$ storage (CGAQIQ and CNSMC, 2005). Similarly, the levels of lead did not exceed the $0.1 \mathrm{mg} / \ell$ limit for reclaimed water in urban areas after 24, 120 and $144 \mathrm{~h}$ storage (CWM, 2006), implying that selection of the material used for filling reservoir structures of porous asphalt pavements depends on the intended use of the outlet water. In this study, the water drained from porous asphalt pavement models with limestone-filled reservoirs, was better suited to irrigation water; however, porous asphalt pavement models with 'basalt+limestone'-filled reservoirs appears to be better suited for reclaimed water in urban areas.

\section{Change in zinc concentration}

Changes in total zinc concentration in the effluents over the storage period are shown in Fig. 7 and Table 4. Unlike the decrease in total lead concentrations in the first $4 \mathrm{~h}$ of storage (Fig. 6), the total zinc concentrations in effluents showed significant fluctuations in 'basalt+limestone', basalt, and limestone reservoirs (Fig. 7). Particularly worth noting is the concentration of zinc in the basalt reservoir, which increased significantly from 0.51 to $12.27 \mathrm{mg} / \mathrm{\ell}$ after $2 \mathrm{~h}$, higher than the 'basalt+limestone', and limestone reservoirs during all sampling events within the first $24 \mathrm{~h}$. Remarkable increases in zinc concentrations in the 'basalt+limestone' and limestone reservoirs appeared at $16 \mathrm{~h}$. After this stage, the concentrations of

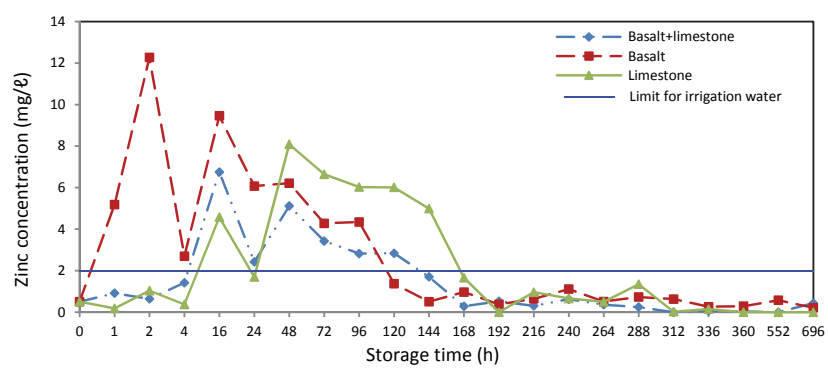

Figure 7

Changes in zinc concentration over the storage period of $696 \mathrm{~h}$

zinc in effluents from the limestone reservoir were substantially higher than the 'basalt+limestone' and basalt reservoirs at each sampling event between 48 and $168 \mathrm{~h}$. There were no significant fluctuations in zinc concentrations in all three reservoirs after $168 \mathrm{~h}$. The result implies that porous asphalt pavements with 'basalt+limestone'-, basalt-, and limestone-filled reservoir structures may affect the concentration of zinc in storage water; and the aggregate used in reservoir structures may have significant impacts on the removal of zinc.

The removal rates for zinc from the porous asphalt pavement models with 'basalt+limestone', basalt, and limestone reservoir structures after $696 \mathrm{~h}$ storage were $93.92 \%, 58.24 \%$ and $99.90 \%$, respectively (as shown in Table 4). However, before $264 \mathrm{~h}$ in the 'basalt+limestone', $336 \mathrm{~h}$ in the basalt, and $312 \mathrm{~h}$ in the limestone reservoirs, the removal of zinc was not only ineffective but counterproductive. The results show that porous 
asphalt pavements with 'basalt+limestone'-, basalt-, and limestone-filled reservoir structures cannot effectively remove zinc from road runoff in the short term.

Aggregate material was not cleaned prior to being used in the reservoirs in order to better simulate conditions in field. The increase in zinc levels may be attributed to the dissolution process of the reservoir aggregate constituents, or other fine materials from the original aggregate material. The increase of $\mathrm{pH}$ and conductivity in effluents from the 'basalt+limestone', basalt, and limestone reservoirs implies excessive ions and products appearing in the stored water. However, there is no direct evidence that excessive zinc in effluent was related to aggregate dissolution. In addition, previous studies have explored the use of limestone as a sorbent for heavy metal pollutants from solution (Liu et al., 2010). Al-Degs et al. (2006) found removal of $\mathrm{Zn}(\mathrm{II})$ ions from solution via ion-exchange mechanisms. Further research is required to investigate the removal of zinc from stored water using porous asphalt pavements with clean reservoir aggregates under the same storage conditions.

The levels of zinc in effluents from the 'basalt+limestone'-, basalt-, and limestone-filled reservoirs did not exceed the 2.0 $\mathrm{mg} / \mathrm{\ell}$ limit for irrigation water after 144, 120 and $168 \mathrm{~h}$ storage (CGAQIQ and CNSMC, 2005), suggesting water extracted from the 'basalt+limestone', basalt, and limestone reservoirs can be used for irrigation after 144, 120 and $168 \mathrm{~h}$. However, using the water extracted from porous asphalt pavements with the abovementioned reservoirs, as reclaimed water in urban areas, should be carefully considered due to a lack of corresponding standards and guidelines in China.

The results indicate that there is potential for porous asphalt pavements with reservoir structures to be used as a suitable technology with respect to road runoff reuse and irrigation in urban areas. Further research is required to explore the attenuation of heavy metals (or other pollutants) in a shorter storage time by using appropriate structures and materials of porous asphalt pavements with reservoir structures.

\section{CONCLUSIONS}

This research demonstrates that porous asphalt pavement models with 'basalt+limestone'-, basalt-, and limestone-filled reservoir structures have the ability to remove lead and zinc from road runoff over a long storage period; all three pavement models showed increasing $\mathrm{pH}$ and conductivity of stored water. The concentrations of lead and zinc in the initial flush were reduced significantly, by over $87.72 \%$ and $62.55 \%$, respectively, for all pavement models. Significant overall reductions in the concentrations of lead and zinc were notable, even following the remarkable increases in the levels of zinc during the first $16 \mathrm{~h}$. The change in lead and zinc levels indicates that caution must be taken when using water for irrigation on crops before $168 \mathrm{~h}$ storage. The concentrations of lead below the limits for reclaimed water, with longer storage time (from 168 to $312 \mathrm{~h}$ ), suggest that stored water used as reclaimed water in urban areas should be carefully considered, and further treatment may be required. Further research is needed to improve the removal capacity of porous asphalt pavements with applicable material in reservoir structures, with respect to heavy metals such as lead and zinc, particularly over a shorter storage time.

\section{ACKNOWLEDGEMENTS}

This work was financially supported by Innovation Program of Jiangsu Graduate Education (CXZZ11_0522) and the Priority
Academic Program Development of Jiangsu Higher Education Institutions (PAPD). The authors thank Kelly Hill from the Division of Information Technology, Engineering and the Environment, University of South Australia, for her language editing which has greatly improved the manuscript.

\section{REFERENCES}

AL-DEGS YS, EL-BARGHOUTHI MI, ISSA AA, KHRAISHEH MA and WALKER GM (2006) Sorption of Zinc (II), Pb(II), and Co(II) using natural sorbents: equilibrium and kinetic studies. Water Res. 40 (14) 2645-2658

BALADĖS JD, LEGRET M and MADIEC H (1995) Permeable pavement: pollution management tools. Water Sci. Technol. 32 (1) 49-56.

BRIGGS J (2006) Performance assessment of porous asphalt for stormwater treatment. M.Sc. thesis, University of New Hampshire.

BROWN C, CHU A, DUIN VAN B and CATERINA V (2009) Characteristics of sediment removal in two types of permeable pavement. Water Qual. Res. J. Can. 44 (1) 59-70.

CGAQIQ and CNSMC (CHINA GENERAL ADMINISTRATION OF QUALITY SUPERVISION, INSPECTION AND QUARANTINE AND CHINA NATIONAL STANDARDIZATION MANAGEMENT COMMITTEE) (2005) Standards for Irrigation Water Quality (GB 5084-2005). CGAQIQ and CNSMC, Beijing, China.

CMC (CHINA MINISTRY OF COMMUNICATIONS) (2006) Specifications for Design of Highway Asphalt Pavement (JTG D502006). China Communication Press, Beijing.

CMC (CHINA MINISTRY OF COMMUNICATIONS) (2011) Standard Test Methods of Bitumen and Bituminous Mixture for Highway Engineering (JTG E20-2011). China Communication Press, Beijing.

CMHURD (CHINA MINISTRY OF HOUSING AND URBANRURAL DEVELOPMENT) (2012) Technical Specification for Permeable Asphalt Pavement (CJJ/T 190-2012). China Building Industry Press, Beijing.

CWM (CHINA WATER MINISTRY) (2006) Standards of Reclaimed Water Quality (SL368-2006). China Water Ministry, Beijing, China.

DANG Z and HOU Y (1995) Experimental study on the dissolution kinetics of basalt-water interaction. Acta Petrologica Sinica 11 (1) 9-15.

DAVIS AP, SHOKOUHIAN M, SHARMA H, MINAMI C and WINOGRADOFF D (2003) Water quality improvement through bio retention: lead, copper, and zinc removal. Water Environ. Res. 75 (1) $73-82$

EPAC (STATE ENVIRONMENTAL PROTECTION ADMINISTRATION OF CHINA) (1987) Water quality - Determination of copper, zinc, lead and cadmium - Atomic absorption spectrometry (GB 7475-87). State Environmental Protection Administration, Beijing, China.

FERGUSON BK (2005) Porous asphalt pavement. In: France RL (ed.) Porous Pavements. CRC Press, Boca Raton, FL.

FIELD R, MASTERS H and SINGER M (1982) An overview of porous pavement research. Water Resour. Bull. 18 (2) 265-270.

FUERHACKER M, HAILE TM, MONAI B and MENTLER A (2011) Performance of a filtration system equipped with filter media for parking lot runoff treatment. Desalination 275 118-125.

HELMREICH B, HILLIGES R, SCHRIEWER A and HORN H (2010) Runoff pollutants of a highly trafficked urban road - correlation analysis and seasonal influences. Chemosphere 80 991-997.

HOGLAND W, NIEMCZYNOWICZ J and WAJLMAN T (1987) The unit superstructure during the construction period. Sci. Total Environ. 59 411-424.

IP CCM, LI XD, WONG CSC and ZHANG WL (2005) Heavy metal and $\mathrm{Pb}$ isotopic compositions of aquatic organisms in the Pearl River Estuary, South China. Environ. Pollut. 138 494-504.

KUENNEN T (2003) A new era for permeable pavements. Better Roads 73 (4) 28-35.

LEE JY, KIM H, KIM Y and HAN MY (2011) Characteristics of the event mean concentration (EMC) from rainfall runoff on an urban highway. Environ. Pollut. 159 884-888. 
LEGRET M and COLANDINI V (1999) Effects of a porous pavement with reservoir structure on runoff water: water quality and rate of heavy metals. Water Sci. Technol. 39 (2) 111-117.

LEGRET M, COLANDINI V and MARC LC (1996) Effects of a porous pavement with reservoir structure on the quality of runoff water and soil. Sci. Total Environ. 189/190 335-340.

LEGRET M, NICOLLET M, MILODA P, COLANDINI V and RAIMBAULT G (1999) Simulation of heavy metal pollution from stormwater infiltration through a porous pavement with reservoir structure. Water. Sci. Technol. 39 (2) 119-125.

LIU JG, TANG Y and CHEN L (2010) Experimental study on adsorption of trace determination of molybdenum by limestone. J. Hohai Univ. (Nat. Sci.) 38 (3) 300-303.

MURAKAMI M, FUJITA M, FURUMAI H, IKURO K and KURISU F (2009) Sorption behaviour of heavy metal species by soakaway sediment receiving urban road runoff from residential and heavily trafficked areas. J. Hazardous Mater. 164 707-712.

MYERS B, BEECHAM S and VAN LEEUWEN J (2011) Water quality with storage in permeable pavement basecourse. Proc. ICE Water Manage. 164 361-372.

MYERS B, SAGI I, VAN LEEUWEN J and BEECHAM S (2007) Water quality improvement by base course aggregate in a permeable pavement with underlying reservoir structure. In: Proc. $13^{\text {th }}$ International Rainwater Catchment Systems Conf., $5^{\text {th }}$ International Water Sensitive Urban Design Conf., 21-23 August, Sydney, Australia.

NIE FH, LI T, YAO HF, FENG M and ZHANG GK (2008) Characterization of suspended solids and particle-bound heavy metals in a first flush of highway runoff. J. Zhejiang Univ. Sci. A 9 (11) 1567-1575.

ROSEEN RM, BALLESTERO TP, HOULE JJ, BRIGGS JF and HOULE KM (2012) Water quality and hydrologic performance of a porous asphalt pavement as a stormwater treatment strategy in a cold climate. J. Environ. Eng. 138 (1) 81-89.

SHINYA M, TSUCHINAGA T, KITANO M, YAMADA Y and ISHIKAWA M (2000) Characterization of heavy metals and polycyclic aromatic hydrocarbons in urban highway runoff. Water Sci. Technol. 42 (7-8) 201-208.

SINGH KK, SINGH U, SINGH BP and YADAY A (2011) Removal of heavy metals from highway runoff using agricultural waste wheat bran. Asian J. Biochem. Pharm. Res. 1 (1) 9-18.

SINGHAL N, ELEFSINIOTIS T, WEERARATNE N and JOHNSON A (2008) Sediment retention by alternative filtration media configurations in stormwater treatment. Water Air Soil Pollut. 187 173-190.

UKABIALA CHINWE O, NWINYI OBINNA C, AKEEM A and ALO BI (2010) Assessment of heavy metals in urban highway runoff from Ikorodu Expressway Lagos, Nigeria. J. Environ. Chem. Ecotoxicol. 2 (3) 34-37.

VARDANYAN LG and INGOLE BS (2006) Studies on heavy metal accumulation in aquatic macrophytes from Sevan (America) and Carambolim (India) lake systems. Environ. Int. 32 208-218.

XIE XG, XU YP and CUI FY (2009) Controlling efficiency of permeable pavement to runoff pollutant. J. Harbin Inst. Technol. 41 (9) 56-60.

XING M (2007) Study on the removal of $\mathrm{Pb}^{2+}, \mathrm{Cd}^{2+}$ ion in sewage by limestone. Masters thesis, Sun Yat-Sen University, Guangzhou.

XU FG, TANG J and GAO SX (2008) Simulated acid rain on the deteriorated action of calcite and its surface corrosion. Ecol. Environ. 17 (6) 2445-2449.

YU AH, SHI D and ZHAO C (2008) Water characteristics of highway asphalt pavement runoff. J. Nanjing For. Univ. (Nat. Sci. Edition) 32 (5) 149-152.

ZHANG ZM, CUI BS and FAN XJ (2012) Removal mechanisms of heavy metal pollution from urban runoff in wetlands. Front. Earth Sci. 6 (4) 433-444.

ZHAO Y and ZHAO C (2012) Research on the purification ability of porous asphalt pavement to runoff pollution. Adv. Mater. Res. 446449 2439-2448.

ZUO XJ, FU DF and LI H (2012) Speciation distribution and mass balance of copper and zinc in urban rain, sediments, and road runoff. Environ. Sci. Pollut. Res. 19 (9) 4042-4048. 